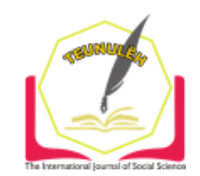

Jurnal Ilmiah Teunuleh

The International Journal of Social Sciences

Vol. 1, Issue. 1, Sept 2020

E-ISSN: 2746-4393

\title{
WRITING INTERPRETATIONS IN INDONESIA CLASSICAL AND MODERN TIMES
}

\author{
Muhammad Faisal \\ STAIN Teungku Dirundeng Meulaboh \\ muhammadfaisal@staindirundeng.ac.id
}

\begin{abstract}
The interpretation of the Qur'an has begun from the time of the Prophet (s) until it continues to develop over time, the development of interpretation of the Qur'an is inseparable from the problem of life that continues to grow according to its time. Therefore the interpretation model of the Qur'an also has characteristics, as well as different methods. The difference in interpretation model of the Qur'an also occurs in Indonesia. This article focuses on discussing the development of interpretation writing in Indonesia which is divided into two categories, namely scientific and non-scientific. In the context of socializing the worldview of the Quran, the writing of interpretations in Indonesia in the 1990s moved with two forces. First, strength in a hermeneutic context. Second, the writing of interpretation is placed as a socio-societal movement.
\end{abstract}

Keywords: Interpretations, Indonesia, Classical and Modern Times

\section{A. Introduction}

Qur'an study in Indonesia is an interesting study to date. The scientific text of the Qur'an which includes the writing of translations and interpretations of the Qur'an, research on the ancient mushafs of the Archipelago, various arts related to the Qur'an, as well as research on the use of the Qur'an in society have interesting variations. So the breadth of the study becomes a great potential for observers of the Qur'an to research it further. The things to note in the study of the Qur'an in Indonesia itself have the peculiarities and characteristics of local Indonesia both verbally and in writing. 
In Indonesia, interpretation writing has its own categories, such as scientific and non-scientific forms of interpretation. In fact, this categorization is more about the writing system used when the interpretation was made, which is different in general to the earlier interpretations. Some modern-century commentary writings tend to use the systematics of scientific writing, such as the use of footnotes, reading references and others. This is the object of study in the discussion of this article, the writing of interpretations in Indonesia in scientific and non-scientific frames, and the orientation of the writing of the interpretation as its significance to the development of the present.

\section{B. Periodation of Indonesian Tafseer Literature}

In terms of generations, Howard M. Federspiel has been sharing the emergence and development of interpretations of the Quran in Indonesia, which is based on years, in three generations. The first genesari, roughly from the beginning of the 20th century to the early 1960s. In this era it has been characterized by a separate and inclined interpretation of certain surahs over the first generation, which emerged in the mid1960s. The feature, usually has several notes, footnotes, word-for-word translations, and sometimes comes with a simple index. The third generation commentary, beginning to emerge in the 1970s is a complete interpretation, with extensive commentaries on the text accompanied by its translation. ${ }^{1}$

Federspiel's categorization is indeed useful in order to see the dynamics of interpretation writing in Indonesia. However, from theegi of his election year it seemed a bit chaotic. He included three works of interpretation, namely;

1. Al-Furqan, Tafsir Al-qur'an (Jakarta: Tintamas, 1962) by Ahmad Hassan;

2. Tafsir Al-qur'an by H. Zainuddin Hamidy and Fachruddin Hs. (Jakarta: Wijaya, 1959);

3. Tafsir Quran Karim (Jakarta: P.T. Pustaka Mahmuddiyah, 1957) by H. Mahmud Yunus, As a work of interpretation that he thinks is representative to represent the second generation. ${ }^{2}$ In fact, all three works had appeared in the mid and late 1950s, which in the categorizations he compiled came in the first generation.

Similar confusion also occurred when he included Tafsir Al-Bayan (Bandung: PT. Al-Ma'arif, 1966) by TM. Hasbi Ash-Shiddieqy, Tafsir Al-Qur'anul Karim (Kuala

\footnotetext{
${ }^{1}$ Howard M. Federspiel, Kajian Al-Quran di Indonesia, p. 129.

${ }^{2}$ Howard M. Federspiel, Kajian Al-Quran di Indonesia, p. 129.
} 
Lumpur: Pustaka Antara, 1969/Medan, 1955) by M. Halim Hasan et al., and Tafsir AlAzhar (Jakarta: Pembina Masa, 1967, cet. I) hamka's work in the third generation. In terms of the year of publication, the three works of this interpretation are seen, that Tafsir Al-Bayan by Hasbi Ash-Shiddieqy is categorized in the second generation, Tafsir AlQur'anul Karim Halim Hasan et al, is included in the first generation, and Tafsir AlAzhar by Hamka is in the third generation.

In terms of the mapping that Federspiel did above, consistently in the period of the year, mapping the works of the Qur'an interpretation in Indonesia remains important to look at the dynamics, both in terms of the technical writing and interpretation methods, as well as the nature of interpreters in each decade. Based on these considerations, the following is presented the category of interpretation of the Qur'an in Indonesia by referring to the periodation of the year by displaying the technical forms of writing. ${ }^{3}$

\section{First Period: Early 20th century to 1960s}

In this period of petama, the tradition of interpretation in Indonesia moves in a simple model and technical writing. In terms of the material of the text of the Quran that became the object of interpretation, the literature of interpretation in this first period is quite diverse. First, there is the literature of interpretation that concentrates on certain surahs as objects of interpretation, for example, Tafsir Al-Qur'anul Karim, Yasin (Medan: Islamiyah, 1951) by Adnan Yahya Lubis; Commentary on Surah Yasien with Description (Bangil: Persis, 1951) by A. Hassan. Both of these commentaries concentrate on the Surah Yasin.

Still in the context of the object of certain surah interpretations, some concentrate on surah Al-Fatihah, namely: Tafsir Al-Qur'anul Karim, Surah Al-Fatihah (Jakarta: Widjaja, 1955) by Muhammad Nur Idris, Rahasia Ummul Qur'an or Tafsir Surat AlFatihah (Jakarta: Institute Indonesia, 1956) by A. Bahry, Kandungan Al-Fatihah (Jakarta: Pustaka Islam, 1960) by Bahroem Rangkuti, and Tafsir Surat Al-Fatihah (Cirebon: Toko Mesir, 1969) by H. Hasri.

${ }^{3}$ The categorization of the period using the size of the year here is similar to that of Federspiel, namely: the first generation was the beginning of the 20th to early 1960s, the second generation of the mid-1960s, and the third generation of the 1970s. However, the results are different. 
Second, a work of interpretation that concentrates on a particular juz's. In this section that appears only the 30th juz (juz' Amma) which becomes the object of interpretation. Examples of this model are: Al-Burhan, Tafseer Juz' Amma (Padang: AlMunir, 1922) by $\mathrm{H}$. Abdulkarim Amrullah, Al-Hidayah Tafsir Juz'amma (Bandung: AlMa'arif, 1930) by A. Hassan, Tafsir Djuz 'Amma (Medan: Islamiyah, 1954) by Adnan Yahya Lubis, Tafsir Al-Qur'anul Karim: Djuz 'Amma (Jakarta: Wijaya, 1955) by Zuber Usman, Tafsir Juz' Amma in Indonesian (Bandung: Al-Ma'arif, 1958) by Iskandar Idris, AlAbroor, Tafsir Djuz 'Amma (Surabaya: Family Business, 1960) by Mustafa Baisa, and Tafsir Djuz 'Amma in Indonesian (Bandung: Al-Ma'arif, 1960) by M. Said.

Third, some interpret the Quran intact 30 juz, namely Tafsir Quran Karim (Jakarta: Pustaka Mahmudiyah, 1957 print VII) by H. Mahmud Yunus which was first completed in 1938. Then Tafseer Al-Qur'anul Karim Hassan, H. Zainal Arifin Abbas, and Abdurrahman Haitami, Tafsir Al-Qur'an (Jakarta: Wijaya, 1959) by H. Zainuddin Hamidy and Fachruddin Hs., Al-Furqan: Tafsir Al-Qur'an (Jakarta: Tintamas, 1962) by Ahmad Hassan, Tafsir AlAzhar (Jakarta: Pembina Mas, 1967, cet. I) by Haji Abdulkarim Amrullah (Hamka), and Tafsir Al-Bayan (Bandung: Al-Ma'arif, 1966) by T.M. Hasbi Ash-Shiddieqy.

In terms of the nature of mufassir, in this first period appeared the writing of interpretations done collectively, namely written by more than one mufasir person. This can be seen, for example in Tafsir Al-Qur'an Al-Karim, (Medan; Islamiyah Firm, 1956, 9th edition) compiled by H.A. Halim Hassan, H. Zainal Arifin Abbas and Abdurrahman Haitami, and Tafsir Al-Qur'an (Jakarta: Wijaya, 1959) compiled by H. Zainuddin Hamidy and Fachruddin Hs.

The description above shows that in terms of the object of interpretation, in the early period, juz' Amma and surah Yasin turned out to be one of the objects of interpretation chosen and liked by the mufasirs. This is the case, assumed because from the beginning, juz' Amma and surah Yasin were among the parts of the Quran that were quite popular among Indonesian Muslims. In the tradition of learning to read the Quran, as used in the Baqdadiyyah method, which in the world of pesantren is known by the term follow-up, we can find where juz'Amma became the earliest teaching material. As for the choice of surah Yasin, it is assumed that this surah is often read by some Muslims in a certain momentum, such as on Fridays or in kenduri events. ${ }^{4}$ From the above assumptions, it is actually the tradition of interpretation that specifically chooses

\footnotetext{
${ }^{4}$ About the tradition of recitation of the Surah Yaasiin on a certain day and momentum carried out by some Muslims, Achmad Sunarto, Majmu'Syarif (Kudus: Menara, t.th), p. 2
} 
juz'Amma and or yasin surah is not typical of Indonesia. Because, this kind of model is also used by some writers of interpretation from outside Indonesia.

\section{Second Period: 1970 s to 1980 s}

Some technical models of presentation and interpretation objects in the first period also still appear in the second period. The commentary literature that directs the object of its interpretation to a particular surah can still be found. For example, the interpretation work specializing in surah Al-Fatihah, namely: Samudra AlFatihah (Surabaya: Arini, 1972) by Bey Arifin, Tafsir Ummul Qur'an (Surabaya: Al-Ikhlas, 1981) by M. Abdul Hakim Malik, Mutiara Al-Fatihah (Surabaya: Bintang Pelajar, 1986) by Labib MZ and Maftuh Ahnan, Risalah Fatihah (Bangil: Yayasan Al-Muslimun, 1987) by A. Hassan, Tafsir Surat Yaasien (Jakarta: Bulan Bintang, 1978) by Zainal Abidin Ahmad, and Kandungan Surat Yasin (t.tp.: Yulia Karya, 1978) Mahfudli Sahli.

The commentary literature that concentrates on the entire Quran 30 juz also we find in the second period, namely: Translation and Interpretation of the Quran: Arabic and Latin letters (Bandung: F.A. Sumatera, 1978) by Bachtiar Surin, and Tafsir Rahmat (Jakarta: Mutiara, 1983, print II) by H. Oemar Bakry.

In terms of the nature of the interpretation, conducted collectively, also appeared in the second period, namely: Mutiara Al-Fatihah (Surabaya: Bintang Pelajar, 1986) by Labib MZ and Maftuh Ahnan. Even the collectivity of mufasir, in this second period there is institutionalized in a special committee consisting of many people. This phenomenon is seen in the Qur'an and its Commentary (Jakarta: Yayasan Penyelenggara Translator/Interpreter of the Quran 1975, 11 volumes), which is handled by the Ministry of Religious Affairs of the Republic of Indonesia. ${ }^{5}$

New developments occurred in this second period, where the work of interpretation appeared that concentrated on the hokum verses. This model can be seen in the book of Verses of Law, interpretation and Description of Commandments in the Qur'an (Bandung: CV. Diponegoro, 1976) written by Q.A. Dahlan Saleh and M.D. Dahlan, and Tafsir Ayat Ahkam, on Some Criminal Acts in Islamic Law (Yogyakarta: Bina usaha, 1984) by Nasikun.

${ }^{5}$ The team members preparing the Quran and its interpretations are Bustami A. Gani (chairman), T.M. Hasbi Ash-Shiddieqy (representative) Kamal Mukhtar (secretary), Gazali Thaib, Syukri Ghazali, A. Mukhti Ali, M. Toha Yahya Umar, A. Soenaryo. Ali Maksum, Busyairi Majdi, Sanusi Latif, and Abdur Rahim, Look Al Quran dan Tafsirnya (Jakarta: Yayasan Penyelenggara Penterjemah/Penafsir Al-Quran, 1975) I; p. xii-xiii. 


\section{Forms of Interpretation Writing}

What is meant by the form of interpretation writing here is a writing mechanism that concerns the technical rules in the preparation of the error of an interpreting literature. The rules in question are the procedure of quoting sources, writing footnotes, mentions of referenced books, and other matters concerning relational construction.

In this regard, there are two main things analyzed: (1) the form of scientific writing, and (2) the nonscientific form of writing. Both forms of this writing will be outlined in the following sections by showing examples of cases in each interpreted work.

\section{Forms of Scientific Writing}

The first part of the form of interpretation writing is a form of scientific writing. What is meant by the form of scientific writing is a very strict interpretation writing in treating its editorial preparation mechanism. In this form, sentences and understandings derived from some other literature are given footnotes or abdominal notes to show the reader the original source of the referenced understanding. Titles, books, places, years, publishers, and book page numbers are important to be spoken in this form of scientific writing.

This form is mostly dominated by commentary works written for academic purposes. The form of scientific writing in general can be seen from two main points. First, the absence of footnotes as a mechanism in explaining the details of the reference literature. Included in this section are the Soul in the Qur'an, the Interpretation of Hatred, the Book of Meanings and Its Scope, the Argument for Gender Equality, the Sufi Interpretation of Al-Fatihah, the Cultural Shaping Man in the Qur'an, and the Kufr Concept in the Qur'an.

Second, the absence of endnote as a mechanism in explaining the details of reference sources. Included in this section are Entering the Meaning of Love, Diving into Human Freedom, and The Concept of Human Deeds According to the Qur'an.

In the process of quoting the mufasir view, this work uses scientific rules, although not rigidly, namely by making stomach notes for all quoted tookoh statesmen. The information provided in the abdominal notes, including: mufasir name, volume number, and book page number. ${ }^{6}$

${ }^{6}$ Look Syu'bah. Asa, Dalam cahaya Al-Qur'an: tafsir ayat-ayat sosial-politik, (Jakarta: Gramedia Pustaka Utama, 2000), p. 40. 
Therefore, although this work is packed with column language style models, it is able to perform with the power of scientific writing. With this form of writing, we can find two important things in this commentary: (1) the books, the interpretation books and the authors referenced, and (2) we can distinguish between the opinions of the authors and the opinions of the quoted figures.

Second, the Encyclopedia of the Qur'an. Similar to in the Light of the Qur'an, this work also uses a form of scientific writing by providing abdominal notes in each statement and pandapat figures and mufasir referenced. The difference, the stomach note model he wears is simpler, namely mentioning the author's name, and only occasionally displays the title of the book and the year it is published. ${ }^{7}$

In some cases, this work of interpretation is inconsistent with the scientific form of writing. For, the citation of the opinion of a person or mufasir, is not accompanied by a reference note, at least the title of the referenced book. This can be seen, for example when this work talks about fithrah. ${ }^{8}$

The third Tafseer bil Ma'tsur. This work, despite its exposure, provides reference notes to some of the histories cited in each description. The model of note-taking used by this work is two: (1) similar to what happened in the Light of the Qur'an, namely themodel of the abdominal note by informing the title of the book, volume number, and page of the book; (2) the reportage of the history he has translated in Indonesian to describe a verse, given a note with the sequence number placed on the left side of the text. While the original text is placed on the end sheet of the book.

Fourth, the Thematic Interpretation of the Qur'an on Inter-Religious Social Relations. This work of interpretation, each time referring to the opinions of the interpreters, as well as in providing an interpretation of the Arabic vocabulary referred to from the dictionary, always provides a reference note. The reference note model used is "endnote".

Fifth, Tafseer bi Al-Ra'yi. The form of scientific writing is similar to that used by the Thematic Interpretation of the Qur'an on Inter-Religious Social Relations, i.e.using a reference note with 'endnote. While the sixth book included in this section is Tafsir Sufi Al-Fataihan, which uses a reference note with the model 'footnote'.

${ }^{7}$ Look M. Dawam Rasardjo, Ensiklopedi al-Qur'an: Tafsir Sosial Berdasarkan Konsepkonsep Kunci, (Jakarta: Paramadina, 1996), p. 245.

${ }^{8}$ Look M. Dawam Rasardjo, Ensiklopedi Al-Qur'an, p. 47. the same cases can be viewed on pages $78,80,108,109,136,155,164,167$ and many more. 


\section{Nonsilmical Writing Form}

The second part of the form of interpretation writing is non-scientific writing. What is meant by the term nonscientific is a form of interpretation writing that does not use the rules of scientific writing that require the existation of: footnotes, endnotes, or abdominal notes, in providing an explanation of the literature referenced. Although it does not use a form of scientific writing, it does not mean a work of interpretation is then claimed, in terms of content, unscientific. The scientific category in this sense has nothing to do with content. This category is only used in the context of mapping the form of writing, not the content of an interpreted book.

The works of interpretation that use this form of nonsilmical writing are seven: Tafsir Al-Misbah, Scripture in Musings, Tafsir Al-Qur'an Al-Karim, Insight of the Qur'an, Understanding Surah Yaasiin, Tafsir Juz' Amma, Divine Dish, Qur'an and Tafseer, and Tafsir Al-Hijri. In all, from the above description it can be concluded that 15 works of interpretation use a form of scientific writing: nine works of interpretation arise from academic duties, six works of interpretation from outside academic duties. While using nonsilmical writing there are nine works of interpretation. See the following table.

Table. Forms of Writing Literature Tafsir Al-qur'an in Indonesia

\begin{tabular}{|c|c|c|c|c|c|}
\hline \multirow{2}{*}{ No } & \multicolumn{4}{|c|}{ PRESENTATION FORM } & $\begin{array}{l}\text { QURANIC LITERATURE } \\
\text { IN INDONESIA 1990- }\end{array}$ \\
\hline & \multicolumn{2}{|c|}{ Shapes } & Systematics & $\begin{array}{c}\text { Publication } \\
\& \text { Origin of Manuscripts }\end{array}$ & $\begin{array}{c}\text { Title of Interpretation } \\
\text { and Author }\end{array}$ \\
\hline 1. & Scientific & $\begin{array}{l}\text { 1. Stomach } \\
\text { Notes }\end{array}$ & $\begin{array}{l}\text { 1. Modern } \\
\text { Thematic }\end{array}$ & $\begin{array}{l}\text { 1. A collection of writings } \\
\text { has been published in } \\
\text { a paper or journal }\end{array}$ & $\begin{array}{l}\text { 1. In the Light of the } \\
\text { Qur'an, The } \\
\text { Interpretation of } \\
\text { Socio-Political } \\
\text { Verses by Shu'bah } \\
\text { Asa } \\
\text { 2. Encyclopaedic } \\
\text { Qur'an, Social } \\
\text { Commentary Based } \\
\text { on Key Concepts } \\
\text { by M. Dawam }\end{array}$ \\
\hline
\end{tabular}


Writing Interpretations in Indonesia Classical and Modern Times

\begin{tabular}{|c|c|c|c|}
\hline \multirow[t]{5}{*}{ 2. Endnote } & $\begin{array}{l}\text { 1. Classic } \\
\text { thematic }\end{array}$ & $\begin{array}{l}\text { 1. A collection of writings } \\
\text { published in } \\
\text { newspapers }\end{array}$ & $\begin{array}{l}\text { 1. Tafsir bil Ma'tsur } \\
\text { Moral Message of } \\
\text { the Qur'an by } \\
\text { Jalaluddin Rakhmat }\end{array}$ \\
\hline & $\begin{array}{l}\text { 2. Modern } \\
\text { thematic }\end{array}$ & $\begin{array}{l}\text { 1. Full writing has never } \\
\text { been published }\end{array}$ & $\begin{array}{l}\text { 1. Thematic } \\
\text { Interpretation of } \\
\text { the Qur'an on } \\
\text { Interfaith Social } \\
\text { Relations } \\
\text { by the Tarjih } \\
\text { Assembly and the } \\
\text { Development of } \\
\text { Islamic Thought } \\
\text { PP. Muhammadiyah } \\
\text { 2. Tafseer bi Al- } \\
\text { Ra'yi. Efforts to } \\
\text { Extract The Concept } \\
\text { of Women in the } \\
\text { Qur'an by } \\
\text { Nashruddin Baidan }\end{array}$ \\
\hline & & 2. Thesis & $\begin{array}{l}\text { 1. Entering the } \\
\text { Meaning of Love } \\
\text { by Abdurrasyid } \\
\text { Ridha }\end{array}$ \\
\hline & & 3. Thesis & $\begin{array}{l}\text { 1. Meyelami Human } \\
\text { Freedom, Study } \\
\text { Critical of The } \\
\text { Conception of the } \\
\text { Qur'an by Machasin }\end{array}$ \\
\hline & & 4. Dissertation & $\begin{array}{l}\text { 1. The Concept of } \\
\text { Human Deeds } \\
\text { According to the } \\
\text { Qur'an by } \\
\text { Jalaluddin Rahman }\end{array}$ \\
\hline 3. Footnote & $\begin{array}{l}\text { 1. Classic } \\
\text { thematic }\end{array}$ & $\begin{array}{l}\text { 1. Previously unpublished } \\
\text { intact posts }\end{array}$ & $\begin{array}{l}\text { 1. Tafsir Sufi Al- } \\
\text { Fatihah, }\end{array}$ \\
\hline
\end{tabular}




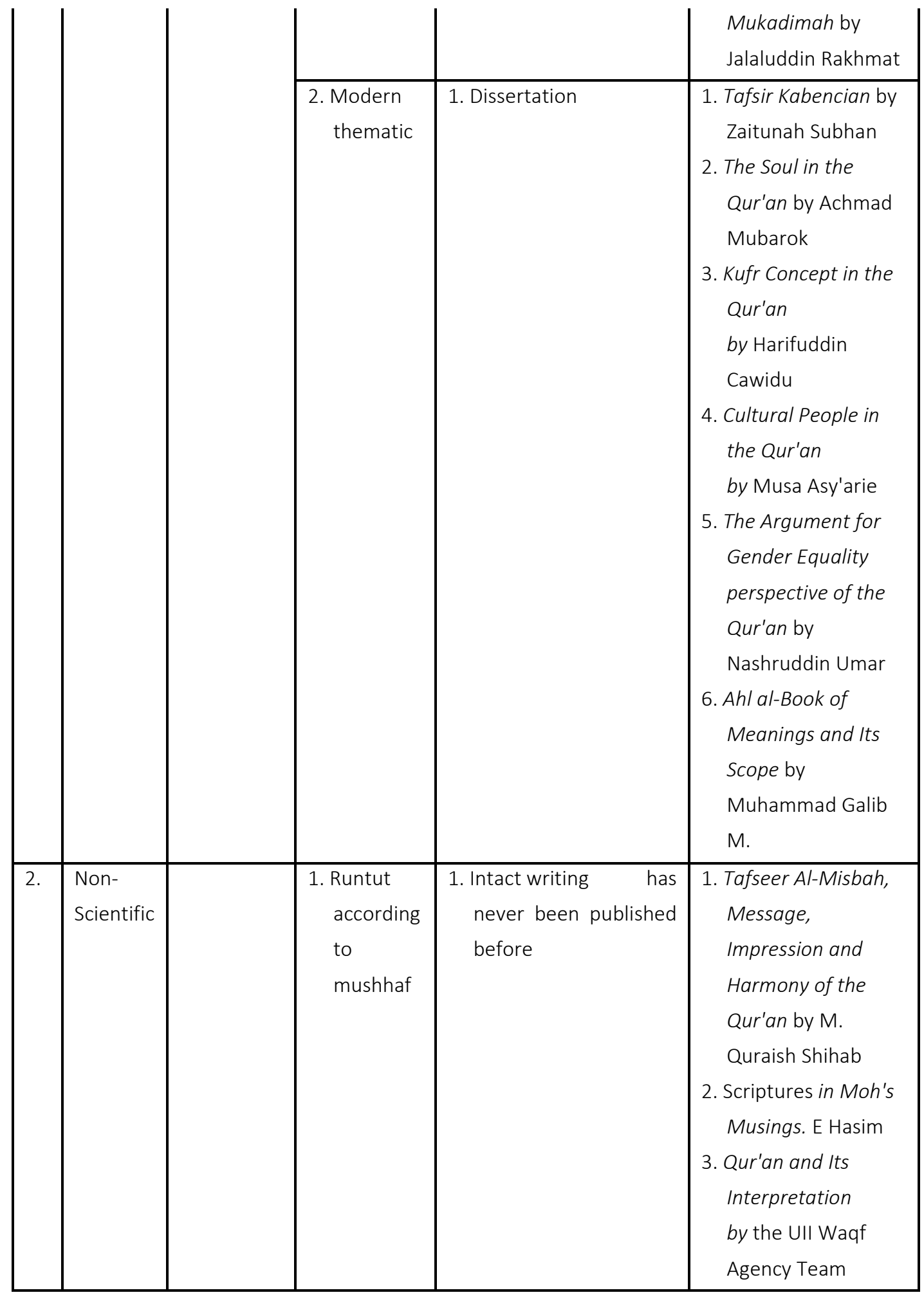


Writing Interpretations in Indonesia Classical and Modern Times

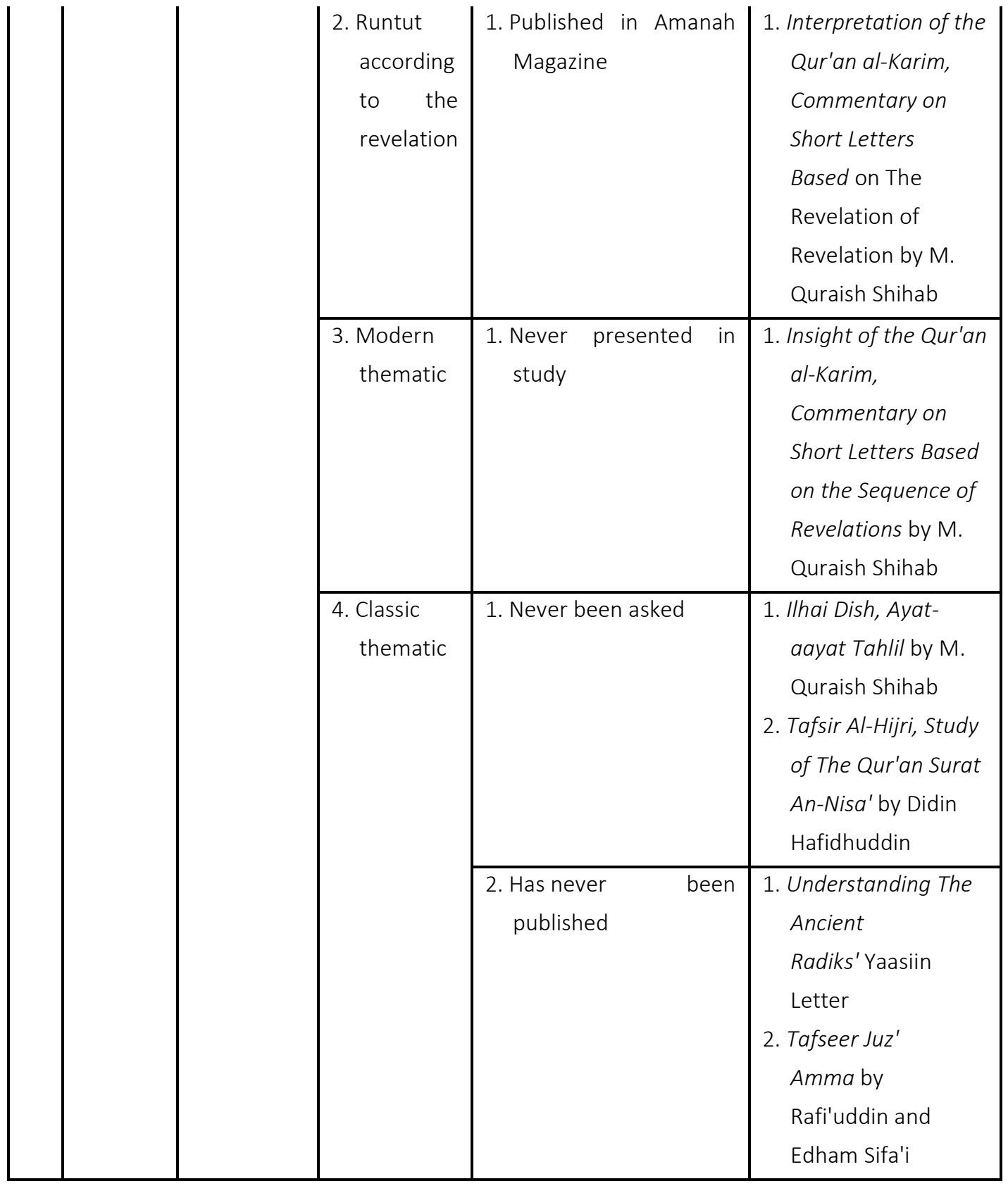

\section{Orientation of Qur'an Interpretation Writing in Indonesia}

In the study of the Qur'an there are two important orientations: (1) the direction of faith that the Qur'an as scripture that instructs mankind (al-ittijah al-hida'i), and (2) the direction of scientific towards the Quran(al-ittijah al-'ilmiyyah). In the direction of orientation of the instructions, the main foundation is usually a more exclusive faith. An 


\section{Muhammad Faisal}

interpretation that begins with this kind of consciousness tends to be less critical of scripture texts. Because, usually this model of direction sees the text of the Quran to the extent that it is a sacred and sacred text, free from the spaces of history. In fact, however, the Qur'an cannot escape the history of Arab society as its audience.

Therefore, people like Abu Zayd emphasize the importance of analyzing the sociocultural background of society at the time the Quran goes down. This is all in order to find a comprehensive view of the World of the Quran. Here, the intellectualization process becomes important in an effort to usher in a comprehensive understanding of Scripture.

In the context of socializing the worldview of the Quran, the writing of interpretations in Indonesia in the 1990s moved with two forces. First, strength in a hermeneutic context. In this direction, contemporary hermeneutics are an important aspect. Especially in the work of interpretations born of academic importance, we can see how this aspect is placed in a very high position. Contemporary hermeneutics have begun to be used in digging up the worldview of the Quran. This phenomenon will lead to a meomentum where interpretation will appear as a scientific product that can be read and understood not only by Muslims, but also people of other religions.

Second, the writing of interpretation is placed as a socio-societal movement. Here, the search for the conception of the Quran as a fundamental value in providing a sociohumanitarian spirit in the lives of the people. The appearance of a partial interpretation of Indonesianism is actually a form of social analysis with the spirit of the Quran that seeks to formulate the idea of the Quran in social praction.

With regard to the above orientation, the choice of introductory language that generally uses Indonesian finds its significance. In the history of interpretation writing tradition in Indonesia, the language used by writers in Indonesia is quite diverse. In addition to using Arabic and some regional languages, generally the works of interpretation in Indonesia are written in Indonesian. The 24 interpretation literature that became the object of this study shows how indonesian language is one of the important media used is a phenomenon that is not separated from the orientation of writing the above interpretation work.

\section{E. Conclusion}

In general Tafsir in Indonesia has shown good development, since the 1990s Indonesian Muslim scholars like to find themselves as a well-known mufasir figure in his 
time. The form of scientific interpretation writing contributes greatly in the Islamic world, especially in the field of interpretation both among academics and non-academics, because the writing follows a growing theme or issue. The form of writing non-scientific interpretation has its own characteristics, because the purpose of writing this interpretation is to interpret the entire text of the Qur'an by following the composition of the Qur'an in general.

In the context of writing interpretations in Indonesia based on hermeneutic and socio-societal contexts. The orientation of the hermeneutic context is deliberately used in digging up the world view of the Qur'an in order to direct scholars to produce other scientific products around deepening the Qur'an. In its orientation towards social-society is used to understand Indonesian culture as a fundamental value in living the order of life of interfaith people. Because in general, Indonesia has several religions governed by law. Until the birth of several interpretations of the Qur'an in Indonesia can be a guideline for Muslims in Indonesia.

\section{Bibliography}

Alquran, T. P. (1975). Al Quran dan Tafsirnya. Jakarta: Yayasan Penyelenggara Penterjemah/Penafsir Al-Quran.

Asa, S. (2000). Dalam Cahaya Al-Qur'an: Tafsir Ayat-Ayat Sosial Politik. Jakarta: Gramedia Pustaka Utama.

Federspiel, M. H. (1994). Kajian Al-Qur'an di Indonesia. Bandung: Mizan.

Rahardjo, M. D. (1996). Ensiklopedi al-Qur'an: Tafsir Sosial Berdasarkan Konsep-Konsep Kunci. Jakarta: Paramadina.

Sunarto, A. (n.d.). Majmu' Syarif. Kudus: Menara. 